\title{
Basel III Leverage and Capital Ratio over the Economic Cycle in the Czech Republic and its Comparison with the CEE Region
}

\author{
Karel Janda-Oleg Kravtsov*
}

\begin{abstract}
:
This paper investigates the implications and effectiveness of Basel III leverage requirements for the banking sector in the Czech Republic and its comparison with the Central and Eastern European (CEE) region. We discuss the relationships between the leverage and capital ratios and analyse their constraining effects and cyclical qualities. The empirical analysis consists of examination of the correlation patterns between the leverage and capital ratio in relation to the changes in the business cycles. We propose an empirical model that allows testing how the leverage ratios and their variables respond to the changes in the economic cycles of the $\mathrm{CEE}$ region. The analysis of correlation patterns among the variables suggests that the total assets or exposure in contrast to the Tier 1 capital are the main contributors to the cyclical movements. The regression analysis shows that the leverage ratio in normal times is strongly pro-cyclical to the capital ratio and counter-cyclical in the crisis period. The empirical evidence indicating the active balance sheet management in response to the cyclical changes advocates in favour of constraining regulations on the leverage.
\end{abstract}

Key words: Leverage Ratio; Capital Ratio; Basel III; Czech Republic; CEE.

JEL classification: G32, G21, G30.

\section{Introduction}

It is widely believed that one of the causes of the latest financial crisis was the excessive build-up of the on- and off-balance sheet leverage in the banking system. In some cases, banks accumulated excessive leverage while evidently maintaining strong risk-based capital ratios (BCBS, 2014). To address this issue and enhance the banks' resilience to crisis, the Basel Committee in 2010 introduced the minimum leverage ratio as an additional prudential tool to

Karel Janda; University of Economics, Prague, Faculty of Finance and Accounting, Department of Banking and Insurance, W. Churchill Sq. 4, 13067 Prague 3 and Charles University, Institute of Economic Studies, Opletalova 26, 11000 Prague 1, Czech Republic, <karel.janda@vse.cz>.

Oleg Kravtsov; University of Economics, Prague, Faculty of Finance and Accounting, Department of Banking and Insurance, W. Churchill Sq. 4, 13067 Praha 3, Czech Republic, $<$ krao02@vse.cz>.

This paper is a part of a project that has received funding from the European Union's Horizon 2020 Research and Innovation Staff Exchange programme under the Marie Sklodowska-Curie grant agreement No. 681228. We also acknowledge support from the Czech Science Foundation (grant 18-05244S). The views expressed in the paper are those of the authors and not necessarily those of their respective institutions. 
Janda, K. - Kravtsov, O.: Basel III Leverage and Capital Ratio over the Economic Cycle in the Czech Republic and its Comparison with CEE Region.

complement the minimum capital adequacy requirements. Basel III leverage ratio is defined as the Tier 1 capital divided by the on- and off-balance sheet exposure. The leverage ratio should be disclosed in the public reports of financial institutions from 1 January 2015 onwards and should be fully implemented by the start of 2018, following its appropriate review and calibration.

This paper investigates the implications and effectiveness of macro-prudential policy on Basel III leverage ratio as an additional measure to the already existing capital requirements for the banking sector in the CEE and especially in the Czech Republic. We identify the potential binding constraints from the regulatory limits and analyse the interactions among ratios over the country's economic cycle (during the period 2007-2016). The empirical analysis consists of a study of the correlation patterns between the leverage and capital ratios in relation to the economic cycles. We extend the empirical part with a regression analysis that studies how leverage ratios and their variables respond to the changes in the economic cycles. The following points are of primary interest of our analysis. What degree of correlation exists between the leverage and capital ratio and their variables in different economic cycles? How the leverage ratio and its variables respond to the changes in business cycles across the CEE banking sector and in comparison to the Czech and Slovak banks? In general, this paper attempts to investigate the effects of market forces and the regulatory constraints for the banks' adjusting strategies in targeting the leverage and capital structure. The article has the following structure: the introduction and relevant literature review are in Section 1; Section 2 and 3 present the statistics from the Czech banking sector and describe the constraining effects of ratios; the methodology and data are discussed in Sections 4 and 5; the results are presented in Section 5 and Section 6 concludes.

\section{Literature Review}

The financial market regulations and their impact on economies are debated by many researchers (Musílek, 2011). The banking regulations and systematic risk in financial market systems are investigated by Klinger and Teply (2016) with special focus on the capital regulations in studies by Avery and Berger (1991), Estrella et al. (2000), Gropp and Heider (2010). Notably few studies are focusing on the implications caused by interactions among regulatory ratios, for example between the regulatory capital and leverage ratios as risk and non-risk based measures. In the analysis by Adrian and Shin (2008, 2010), Brei and Gambacorta (2016), Kalemli-Ozcan et al. (2011), the cyclical properties of the both ratios are tested taking into account the structural shifts in banks' behaviour during the global financial crisis and its aftermath. They suggest that in normal times, Basel III leverage ratio based on the exposure measure is always more countercyclical 
than other ratios. In contrast to capital ratios, it is a tighter constraint for banks at times of an economy's upturn and a looser constraint during recession.

Nuño and Thomas (2017) argue that the banks' leverage is endogenously determined by market forces. They found that the leverage contributes at least as much as equity to the cyclical movements in total assets and the leverage is negatively correlated with equity. It is positively correlated with assets growth and to a lesser extent with GDP. Similarly, Aymanns and Farmer (2015) indicate that the changes in the leverage cycles from pro-cyclical to countercyclical increase the volatility and feedback loop that lead to spill-over effects from the financial sector to the real economy. They propose a flexible leverage regulation policy that makes it possible to continuously tune the leverage depending on the pro-cyclical to countercyclical phase.

Berardi and Marcelletti (2017) study the information asymmetries because of the inability to distinguish the between economical riskiness and bank misconduct, i.e. risk-shifting behaviour. They stress the complementary nature of both the riskbased and accounting-based ratios. Their theoretical findings disapprove the view that regulations on the leverage incentivise banks on shift in the composition of bank balance sheets toward excessive exposure in risky asset. The impact of capital on bank survival during financial crises and normal times is examined by Berger and Bouwman (2013). While focusing mainly on the economic roles of the capital depending on the bank size and the time period, they indicate that the capital helps to enhance the survival probabilities of small banks at all times and for medium/large banks primarily during periods of the banking crises and where the government support is limited. They indicate that the off-balance sheet activities of banks are impacting the capital and consequently survivability of banks over the crisis.

The effectiveness of the Basel Accords as a regulatory framework and its implications on the Czech banking sector were investigated by Š́torová and Teplý (2014a, 2014b) and Vejdovec and Teply (2012). In a country-specific case study, Kellermann and Schlag (2013) examine the constraint factors from ratios using the data from the Swiss banking sector. For the period 2009 to 2011, the minimum leverage ratio requirement became a binding rule for the major Swiss bank UBS. They point out that the leverage ratio could potentially undermine risk weighting such that banks feel encouraged to take greater risks. Cathcart et al. (2013) investigate the interdependencies and pro-cyclical nature of capital and leverage ratios of the US banking institutions prior to the first 1990-1991 and the second credit crunch of 2007-2009. Their results demonstrate that unlike during the first credit crunch, the leverage ratio during the crisis of 2007-2009 was a binding constraint and generally more to blame for triggering the subprime crisis. Their 
Janda, K. - Kravtsov, O.: Basel III Leverage and Capital Ratio over the Economic Cycle in the Czech Republic and its Comparison with CEE Region.

analysis indicates that the reversal in co-movement patterns between the two ratios was the main reason of the change in binding constraint.

\section{The Leverage and Capital Ratios of the Czech Banking Sector}

Basel III leverage ratio (LR) is defined as the capital measure (the numerator) divided by the exposure measure (the denominator) expressed in percentage:

$$
L R_{t}=\frac{K_{t}}{\operatorname{Exp}_{t}},
$$

where $\mathrm{K}$ denotes the Tier 1 capital and Exp the exposure measure at the end of the reporting period $\mathrm{t}$.

The capital measure is based on the new definition of the Tier1 class of capital as set out by Basel Committee (BCBS, 2011). The exposure measure consists of the sum of the following exposures: on-balance sheet exposures (equivalent of the total assets); derivative exposures; securities financing transaction exposures and off-balance sheet items. Basel Committee proposes the minimum Tier 1 leverage ratio $>3.00 \%$.

In Table 1 and 2, we summarise the historical evolution of the capital and leverage ratios for the 15 largest Czech banks over the economic cycles. The period 20072009 refers to the crisis period and years of 2010-2016 represent recovery and normal times.

The following ratios are evaluated: (a) Basel III leverage ratio (as Tier 1 capital / Exposure measure); (b) the accounting leverage ratio (Tier 1 / Total assets); (c) the capital-to-risk-weighted-assets ratio (Tier $1 /$ Risk-weighted assets); (d) the capital adequacy (Total capital / Risk weighted assets). The first three ratios (a), (b), (c) have different denominators but relate to each other with the same numerator - the Tier 1 capital. The accounting leverage (b) which has total assets on balance sheet in its denominator instead of an exposure points at the impact of off-balance sheet exposures, derivatives and guarantees on Basel III leverage ratio. The capital ratio (d) exhibits the development of the banks' capital adequacy over the period. The capital adequacy ratio relates risk weighted assets to the total capital, i.e. the sum of the Tier 1 and Tier 2 capital in interpretation of Basel Committee. 
Tab. 1 Average leverage and capital ratios in crisis (2007-2009), over the period (2010-2016) and minimum regulatory requirements

\begin{tabular}{lrrc}
\hline & 2007-2009 & $\mathbf{2 0 1 0 - 2 0 1 6}$ & $\begin{array}{l}\text { Min regulatory } \\
\text { requirements* }\end{array}$ \\
\hline Basel III Leverage ratio (Tier1 / Basel III Exposure) & $5.56 \%$ & $6.79 \%$ & $\geq 3.0 \%$ \\
Accounting Leverage ratio (Tier1 / TA) & $6.27 \%$ & $7.69 \%$ & \\
Tier 1 capital ratio (Tier1 / RWA) & $11.32 \%$ & $15.62 \%$ & $\geq 8.5 \% *$ \\
Capital adequacy (Tier1+Tier2 / RWA) & $12.27 \%$ & $16.48 \%$ & $\geq 10.5 \% *$ \\
\hline
\end{tabular}

Source: Annual reports and own calculation (note: all ratios are weighted average by respective denominator i.e. RWA, exposure or total assets).

Note:* minimum regulatory requirements from 2015, incl. capital conservation buffer of $2.5 \%$.

\section{Tab. 2 Average capital and leverage ratios of the 15 largest banks in the Czech Republic (2007-2016)}

\begin{tabular}{|c|c|c|c|c|c|c|c|c|}
\hline \multirow{3}{*}{ Ratios } & \multicolumn{2}{|l|}{ (a) } & \multicolumn{2}{|l|}{ (b) } & \multicolumn{2}{|l|}{ (c) } & \multicolumn{2}{|l|}{ (d) } \\
\hline & \multicolumn{2}{|c|}{$\begin{array}{l}\text { Basel III } \\
\text { Leverage Ratio* } \\
\text { (Tier 1 / Total } \\
\text { assets + off } \\
\text { balance sheet } \\
\text { items) }\end{array}$} & \multicolumn{2}{|c|}{$\begin{array}{l}\text { Accounting } \\
\text { Leverage Ratio } \\
\text { (Tier 1 / Total } \\
\text { assets ) }\end{array}$} & \multicolumn{2}{|c|}{$\begin{array}{l}\text { Tier } 1 \text { Capital } \\
\text { Ratio } \\
\text { (Tier } 1 \text { / RWA ) }\end{array}$} & \multicolumn{2}{|c|}{$\begin{array}{l}\text { Capital } \\
\text { Adequacy } \\
\text { (Tier 1+ Tier } 2 \\
\text { RWA) }\end{array}$} \\
\hline & Avg. & Min & Avg. & Min & Avg. & Min & Avg. & Min \\
\hline $\begin{array}{l}\text { Top } 5 \text { largest } \\
\text { banks }\end{array}$ & $5.9 \%$ & $4.0 \%$ & $7.0 \%$ & $4.4 \%$ & $14.0 \%$ & $7.9 \%$ & $14.9 \%$ & $8.7 \%$ \\
\hline All banks & $6.0 \%$ & $1.9 \%$ & $7.3 \%$ & $2.3 \%$ & $14.5 \%$ & $7.4 \%$ & $15.2 \%$ & $8.6 \%$ \\
\hline
\end{tabular}

Source: Annual reports and own calculation.

Note: *as an approximation of Basel III exposure measure, we consider the total assets plus all off-balance sheet exposure (due to the missing data).

The regulatory guidelines on minimum requirements under the Basel III regime are the following: minimum leverage requirement $\geq 3.0 \%$ BCBS (2011); minimum requirement for the Tier 1 capital of $6.0 \%$ (incl. capital conservation buffer $2.5 \%$ ) $\geq 8.5 \%$ of Risk Weighted Assets (RWA); minimum total capital requirement (sum of the Tier 1 and Tier 2 capital) $\geq 10.5 \%$ of RWA.

The weighted median of all risk- and non-risk based ratios reveals an upward trend during the various economic cycles, newly analysed by Stádník and Miečinskienè (2015). Between the crisis period of 2007-09 and the recovery years 2010-14, the median of the risk-weighted Tier 1 capital ratio increased from $11.3 \%$ to $15.6 \%$, while the leverage ratio in the Basel III regime increased very moderately from $5.6 \%$ to $6.8 \%$. The capital ratio (capital adequacy) increased to an even larger extent from $12.3 \%$ to $16.5 \%$. Teply and Vejdovec (2012) and Matejasak (2015) 
Janda, K. - Kravtsov, O.: Basel III Leverage and Capital Ratio over the Economic Cycle in the Czech Republic and its Comparison with CEE Region.

similarly noted that Basel III requirements on the capital are not presenting a significant constraint because of the historically high capital ratios of the Czech banks. The data show that contrary to the capital ratios, the leverage of the Czech banks might represent potentially larger constraint in terms of meeting the transitional minimum regulatory limits. The mean of the leverage ratio across the sample is around $6.0 \%$ that is overall higher than the leverage level referred to as the minimum requirement $\geq 3.0 \%$.

\section{The Constraining Effects from Both Ratios over the Various Economic Cycles}

By introducing the leverage ratio, Basel Committee pursued several goals. The minimum leverage provides a simple and transparent accounting measure that serves as a non-risk based "backstop" which ultimately serves to protect against the model risk, and the reduction of capital requirements and generally it reinforces risk-based requirements (BCBS, 2014). It captures both the on- and offbalance sheet exposure which in fact could bear significant risks due to the complex and not fully transparent derivative and guarantees exposures. Finally, the primary goal of the leverage is to constraint a build-up of excessive leverage in banking system during the times of credit boom and help to soften the deleveraging processes over the course of the downturn economy cycle.

These cyclical qualities of the leverage and capital ratios have been indicated in several studies (Adrian and Shin, 2008, 2010; Nuño and Thomas, 2017). They suggest that in normal times, the leverage tends to be more pro-cyclical and correlated with real economic activities i.e. the leverage, assets and GDP have a positive correlation. The capital ratios reveal opposite counter-cyclical qualities and seem to be more stable and less pro-cyclical in the crisis times (Brei and Gambacorta, 2016; Kellermann and Schlag, 2013). According to this logic, both the leverage and capital measures represent a binding constraint for the banks in various economic cycles. Depending on which one of the two ratios is the stricter binding constraint, the incentive for the banks' strategies might have different approach according to Atkinson and Blundell-Wignall (2010) and Cathcart et al. (2013).

The constraint factor from both Basel III leverage ratio (LR) and the Tier 1 capital ratio $(\mathrm{CR})$ can be derived from the following transformation in ratios (Berger and Bouwman, 2013). Both ratios have the same numerator (the Tier 1 capital), so we can re-arrange the relation of the Tier 1 capital ratio to the leverage ratio as follows:

$$
\frac{L R_{t}}{C R_{t}}=\frac{\frac{K_{t}}{E X P_{t}}}{\frac{K_{t}}{R W A_{t}}}=\frac{R W A_{t}}{E X P_{t}},
$$


where K denotes a the Tier 1 capital, RWA stands for risk-weighted assets and EXP is the exposure measure (on- and off-balance sheet exposure plus derivatives and guarantees) at the end of the reporting period t. The relationship of risk weighted assets to exposure RWA / EXP refers to the risk-weight, sometimes referred to as the "risk density". It can be understood as an average risk-weight across the bank's portfolio within the regulatory interpretation. The higher risk density suggests that the portfolio contains more risky assets. If we set the relationship between Basel III minimum regulatory requirements on the capital ratio at $8.5 \%$ and the leverage ratio at $3.0 \%$, then we will have a multiple of the risk density as follows $\frac{\mathrm{LR}}{\mathrm{CR}}=\frac{3.0}{8.5} \approx 0.35$ (BCBS, 2017).

In Figure 1, the diagonal line represents points where $8.5 \%$ Basel III Tier 1 target risk-based capital ratio results in the same amount of the required Basel III Tier 1 capital as Basel III Tier 1 leverage ratio of $3.0 \%$ and respectively exhibits the constraining factor from the risk density of portfolio, i.e. 35\%. For the banks above the diagonal line (with the risk density of portfolio > 35\%), the Tier 1 riskbased capital ratio will be the constraining factor. The banks below the diagonal line (with the risk density of portfolio < 35\%) will be constrained by Basel III leverage ratio.

\section{Fig. 1 Constraining effect of Basel III Tier 1 risk-based capital and leverage ratios}

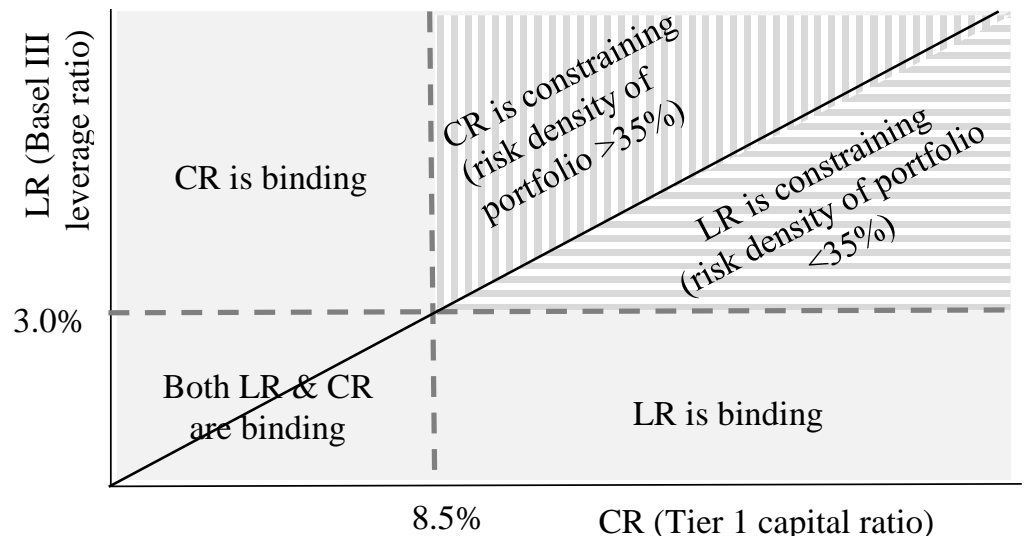

Source: Basel Committee on Banking Supervision (BCBS, 2017) and (Fender and Lewrick, 2015).

The variation in economic cycles impacts the growth and quality of assets on the balance sheets of banks. The financial shocks have negative effects on the investment and output in economy resulting in quality deterioration of the borrowers, consequently affecting the financial assets. If we assume that the risk 
Janda, K. - Kravtsov, O.: Basel III Leverage and Capital Ratio over the Economic Cycle in the Czech Republic and its Comparison with CEE Region.

weights in the regulatory interpretation reflect the riskiness of the portfolio in reality, then the risk-weight should correlate with the economic cycles as noted by Cathcart et al. (2013). In equation (3), where $r w_{i}$ indicates a single risk weight of the assets $A_{i}$ invested by the banks, it is evident how with an increase in the portfolio risk (i.e. higher risk weight) there is a tendency of the capital ratio to move closer to the leverage level:

$$
\lim _{r w_{i} \rightarrow 1} C R=\lim _{r w_{i} \rightarrow 1} \frac{K}{\sum_{i=1}^{N} r w_{i} A_{i}}=\frac{K}{\sum_{i=1}^{N} A_{i}}=L R,
$$

This implies that the risk-based capital requirements tend to be more of a constraining factor, preventing the financial institutions from capital shortage at times of an economic recession or crisis. On contrary, the declining risk weights $\mathrm{rw}_{\mathrm{i}} \rightarrow 0$ in the composition of banking assets could make the financial system more susceptible to shocks because of the overly fast growth in financial assets and higher leverage in the banking system. In such a case, the leverage would serve as a backstop and prevent the accumulation of indebtedness in the system. It implies that during the changes of the economic cycles, both ratios become complementary.

In Figure 2 we observe the historical development of the risk weights over the period of 2007-2016 for the 15 largest Czech banks. Seemingly, it suggests that the Czech banks optimise the risk weighted assets and adjust their business model towards the lower risk portfolios. In such a situation of declining risk density, the leverage is gaining more importance and substantially complements the risk-based requirements.

Fig. 2 Historical development of the risk density of the 15 main banks in the Czech Republic (2007-2016)

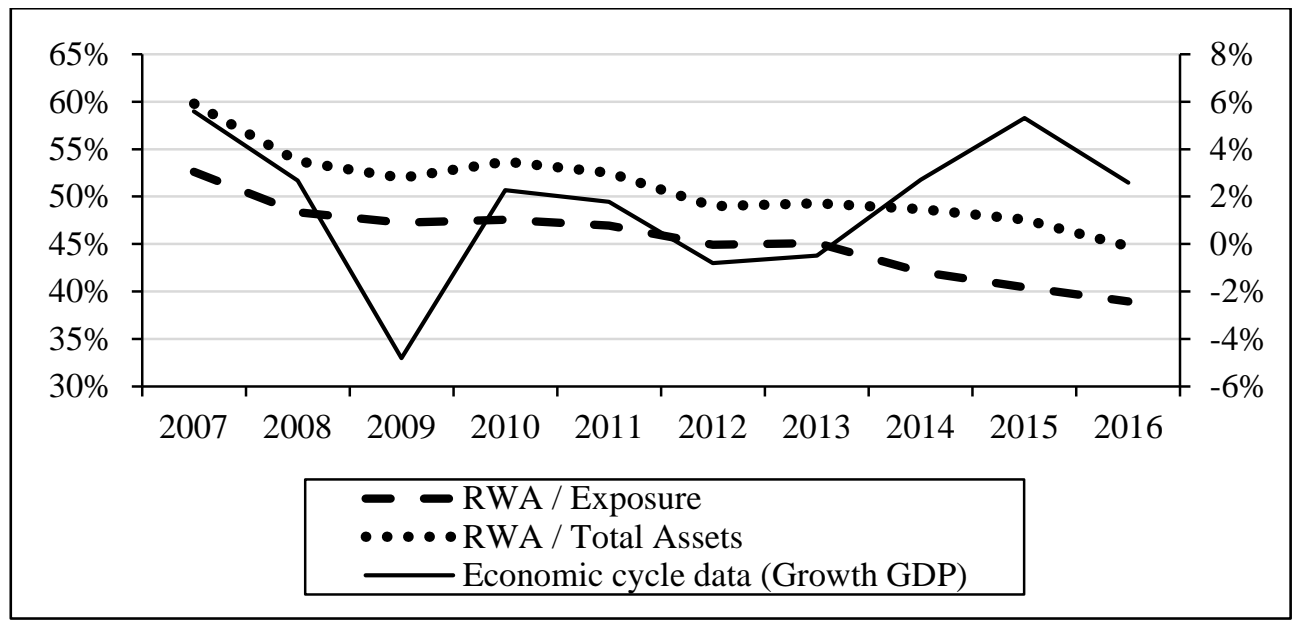

Source: CNB, annual reports and own calculation. 
The annual changes in balance sheets of the Czech banks over the observed period evidently follow the economic cycle with a "reverse" movement of the leverage (expressed by "accounting leverage ratio") versus assets' characteristic for the crisis years 2008-2009 (Figure 3). Overall, adjustments in the leverage (comovement with total assets) reveal a similar pattern to the one described by Adrian and Shin (2010) and Brei and Gambacorta (2016). As explained by these authors, such a strong co-movement signifies an active management of the leverage as the means of expanding and contracting the size of balance sheets to maximise the utility of capital. They suggest that the largest banks might be able to use the increased equity as the basis for further lending which will increase assets (and liabilities) relative to the equity with the outcome that assets and the leverage are no longer inversely related. In other words, the banks are attempting to maximise the capital utility and by doing so they increase their assets respectively. The potential risk is that this way the banks could be incentivised to increase their risk appetite. Given the actual level of capital and confronted with the choice between low risk and low margin, and higher risk but higher margin, most banks will likely opt for the second option according to European Banking Authority Report 2016 (EBA, 2016).

Fig. 3 Annual growth in total assets versus annual change in the leverage for the top 10 Czech banks 2007-2016

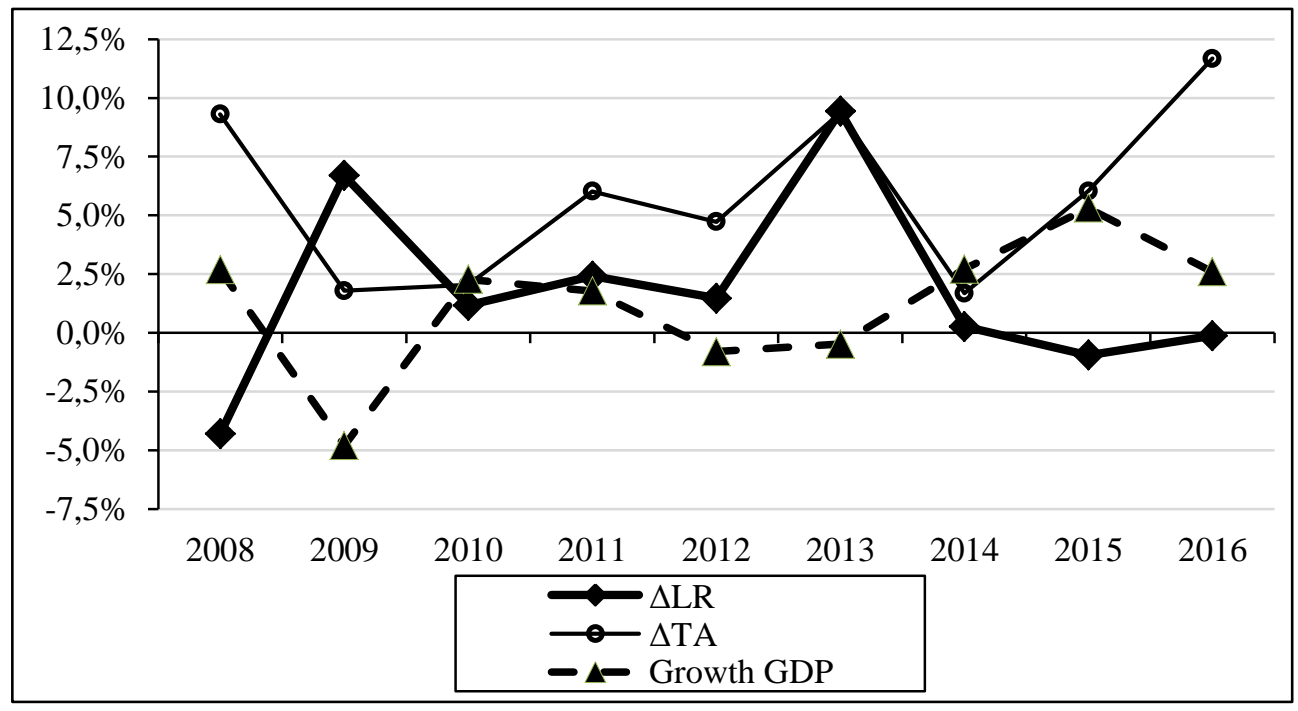

Source: World Bank Statistics, annual reports and own calculations. 
Janda, K. - Kravtsov, O.: Basel III Leverage and Capital Ratio over the Economic Cycle in the Czech Republic and its Comparison with CEE Region.

\section{Data and Methodology}

The empirical analysis consists of two sections. In the first section, we investigate the correlation patterns between the banks' Basel III leverage ratio and the Tier 1 capital ratio in relation to changes in the economic cycles 2007-2016 in the Czech Republic. Building on the studies of Estrella et al. (2000) and Cathcart et al. (2013), we try to capture any interdependencies among the ratios and their response to the changes in economic cycles. In the next section, we extend this analysis and propose an empirical model that allows us to test how Basel III leverage ratio, its variables and the Tier 1 capital ratio respond to the changes in the economic cycles the Czech and Slovak financial institutions and to compare the results for the banks in the CEE region. The interactions between macroeconomic conditions, bank regulations and governmental policies are relevant for all advanced economies and especially for the newly EU integrated economies of the Central and Eastern Europe (Cevik et al., 2016; Janda, 2011; Janda et al., 2013). By introducing the leverage in Basel III framework, Basel Committee aimed exactly at reinforcing the capital requirements with non-risk measures and by this way to mitigate the magnifying effect of the economic cycles.

To find out whether there is any pattern in co-movements of the leverage ratio (accounting leverage ratio $=$ Tier 1 capital $/$ TA) and the Tier 1 capital ratio, we plot the correlation between both ratios (within the sample of 15 Czech banks) over the period 2007-2016 which in our view represents the entire economic cycle. We take as the economic cycle indicators the annual changes in GDP and the loan volume growth. The annual changes in gross domestic product relate to economy conditions and cycles (Fungácová and Jakubík, 2012; Izák, 2011). The loan volume growth in the economy relates to the conditions of the banking sector and thereby reflects the economic cycle indirectly. It is represented by the indicator changes in loans to private sector as \% of the GDP from the official statistics of the World Bank.

The results depicted in Figure 4 demonstrate that a high degree of a positive correlation indeed exists between both ratios (with a range of the coefficient from 0.6 to 0.9 ). The possible explanation for that lies in the components of the ratios and it is mostly attributable to the offsetting effect of an increase in the capital (the Tier 1 capital is a numerator of both ratios) combined with the adjustments in the assets (described in the previous section). The time horizon of our analysis covers the period of constantly increasing capitalisation of the Czech banks driven by stricter regulatory requirements and the business model. The findings by Matejasak (2015) and Teply and Vejdovec (2012) similarly confirm that capital bases of the Czech banks increased substantially over the period 2009-2013 and consequently on average improve the regulatory capital ratios. 
Fig. 4 The correlation of leverage/capital ratio versus the loan volume and GDP growth during 2007-2016

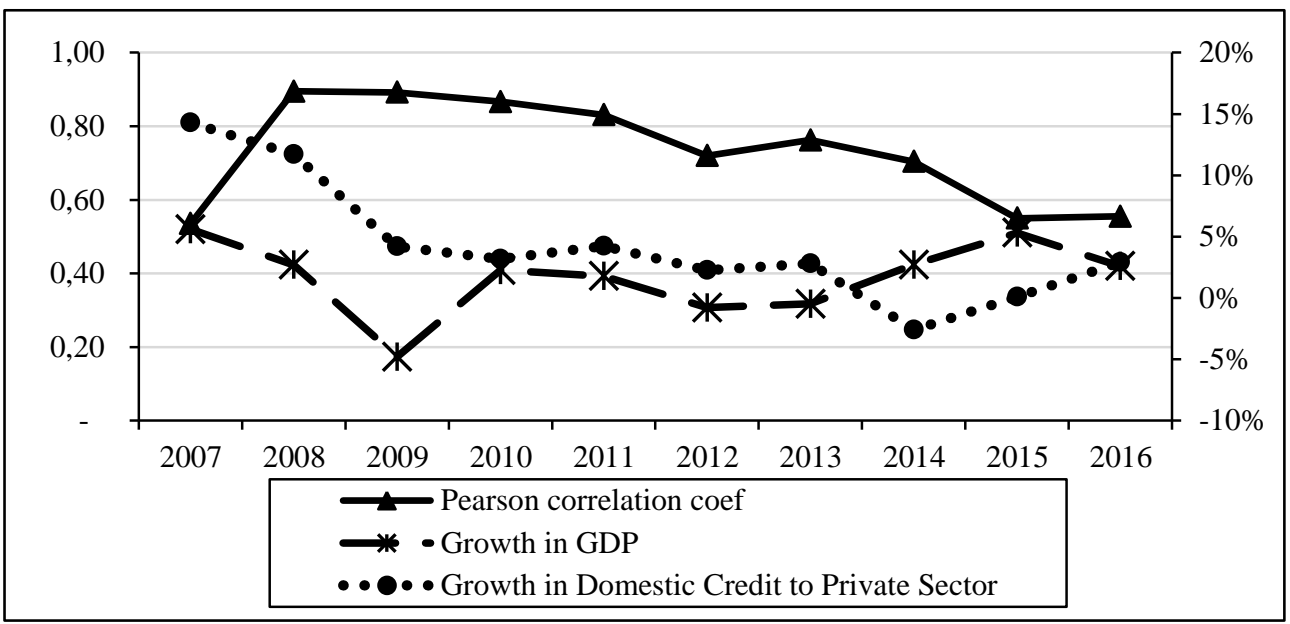

Source: World Bank Statistics, annual reports and own calculations.

The results underline the fact that the leverage and capital ratios tend to co-move at normal times and slightly counter- move at the time of a downturn or upswing. Nevertheless, this does not explain the negative correlation between the leverage versus capital ratio over the crisis period. This implies that the change in the binding constraint from one ratio to another does not explicitly occur during the period of our observation.

To understand the contribution of the individual factors to the fluctuations in the leverage ratio, we analyse and compare the cyclical qualities of the ratios' components. We extract the cyclical components of the variables by applying the cycle band-pass filter for the economic time series of Baxter and King (1999). Based on the statistics of existing business cycles, they developed a set of approximate filters to measure the business cycles of macroeconomic activity. The procedure enables to isolate the business cycle component via transforming the macroeconomic data by applying the moving averages. The filter allows extracting a cyclical component which persists for the periods of two to eight years, and leaves the characteristics of this component undistorted. The cyclical (de-trended) components of the variables were used to compare the volatility of the variables and plot their correlation patterns.

First, we try to assess the contribution of the total assets and the Tier 1 capital to the cyclical fluctuations in the leverage ratio. Secondly, it is of interest for us to estimate how the leverage and capital correlate with each other, and how each component correlates with the total assets. The related question is how the leverage ratio and the assets of banks correlate with the aggregate economic 
Janda, K. - Kravtsov, O.: Basel III Leverage and Capital Ratio over the Economic Cycle in the Czech Republic and its Comparison with CEE Region.

activity, as represented by annual GDP in constant prices and loan to private sector volumes from the official statistics of the World Bank. Furthermore, the certain degree of volatility in the leverage, assets and the Tier 1 capital relative to those in real economic activity is itself a matter of an empirical interest.

Tab. 3 Business cycles and leverage components for the Czech Banks

\begin{tabular}{lrlrr}
\hline & Std. Dev & Correlations & Coefficient & P-values \\
\hline Leverage & 0.0809 & Leverage - Total Assets & $-0.3165^{* *}$ & 0.0001 \\
Tier 1 & 0.1935 & Leverage - Exposure & $-0.3232^{* *}$ & 0.0001 \\
GDP & 0.0272 & Leverage - Capital Tier 1 & $0.6900^{* *}$ & 0.0000 \\
Loan Volumes & 0.0451 & Leverage - GDP & $-0.1767^{* *}$ & 0.0361 \\
& & Leverage - Loan Volumes & 0.1086 & 0.2000 \\
\hline
\end{tabular}

Source: Own calculation, data from World Bank, annual reports.

Note: The sample period is 2007-2016. All variables are natural logarithms. For Excelbased add-in of the Baxter-King band-pass filter, we employ the standard settings BurnsMitchell for annual data, i.e. $\min 2$ and $\max 8$ years, $\mathrm{k}=3$ low-pass filter. Asterisks denote statistical significance of non-zero correlation at the $5 \%(* *)$ confidence level.

The aggregated results are exhibited in Table 3 and can be summarised in the following points. The leverage in the sample is less volatile than the Tier 1 capital but it fluctuates more than economic indicators GDP and the loan volumes' growth. The standard deviation of the leverage ratio is half of the Tier 1 capital and the loan volume growth. The higher volatility in a variable might suggest a larger possible error in evaluating the cyclical co-movement patterns with other variables. The capital Tier 1 has a strong positive correlation with the leverage ratio; it conforms to the mathematical logic of the ratio. The total assets or exposure show a significant contribution to the cyclical movement of the leverage. It reiterates the observations by Adrian and Shin (2010) and Brei and Gambacorta (2016) and points out that the leverage ratio will represent a tighter constraint in the upturn cycle by expanding the balance sheet and a looser one in the recession period when assets are shrinking.

Not surprisingly, the leverage and total assets show a negative correlation with the economic cycle indicator "loans to private sector". However, we observe a negative correlation of the leverage with GDP. The degree of correlation is low, possibly due to the delayed macro effect on the banking sector. 


\section{Panel Data Regression Analysis}

We extend our analysis with the regression model to evaluate and compare the evidences obtained from the empirical part described in previous sections. The cross-geographical comparison of the results is of interest for us, too. There are three main hypotheses that the equation (4) seeks to test:

- Which of the components attribute most to the fluctuations in Basel III leverage ratio because of the changes in economic cycles?

- How do Basel III leverage ratio and the risk-weighted capital Tier 1 ratio react to changes in the business cycle? Do they behave pro-cyclically $(\beta>0)$ or counter-cyclically $(\beta<0)$ ?

- Do these effects change in response to the financial crisis $(\beta \neq \delta)$ ?

The regression model with a fixed effect is applied to the panel data containing the financial data of 320 banking institutions based in the following countries: Czech Republic, Slovakia, Slovenia, Poland, Hungary, Romania and Croatia. These countries in our view represent a relatively similar set up in the banking sector and show evidences of the business cycle synchronisation as noted by Cevik et al. (2016). The financial data is represented by annual financial statements obtained from the database BankFocus and cover the period of 2007-2016. Although, the financial data do not fully reveal details about the exposure measure to calculate it precisely according to the Basel III methodology, in our calculation we used the total assets plus off-balance sheet exposure figures as the best possible approximation. The summary of variables for the regression model is provided in Table 4. The unbalanced data sample is due to the partly missing data for the entire period, mostly for the smallest banks in the dataset.

By performing the regression analysis we have to differentiate the cyclical properties of the ratios in normal times and during the crisis. We address this issue by introducing the dummy $C_{t}$ with the regression variables that is allowing for a parameter shift in the estimated response depending on the condition of the economy.

\section{Tab. 4 Descriptive statistics and definitions for the regression variables}

\begin{tabular}{llccccc}
\hline $\begin{array}{l}\text { Variable } \\
\text { name }\end{array}$ & Variable description & Obs & Mean & $\begin{array}{l}\text { Std. } \\
\text { Deviation }\end{array}$ & Min & Max \\
\hline Y & Year & 1283 & 2012 & 3.1 & 2006 & 2016 \\
& $\begin{array}{l}\text { Tier 1 Capital / } \\
\text { Total Assets + Off Balance Sheet }\end{array}$ & 1283 & 0.08 & 0.08 & -0.13 & 0.98 \\
& $\begin{array}{l}\text { Exposure, in \% } \\
\text { TA }\end{array}$ & 1283 & 7.38 & 1.83 & 1.63 & 11.08 \\
T1 & Tieral Assets (ln) & 1283 & 5.18 & 1.69 & -2.02 & 8.79 \\
\hline
\end{tabular}


Janda, K. - Kravtsov, O.: Basel III Leverage and Capital Ratio over the Economic Cycle in the Czech Republic and its Comparison with CEE Region.

\begin{tabular}{|c|c|c|c|c|c|c|}
\hline $\begin{array}{l}\text { Variable } \\
\text { name }\end{array}$ & Variable description & Obs & Mean & $\begin{array}{l}\text { Std. } \\
\text { Deviation }\end{array}$ & Min & Max \\
\hline TR1 & $\begin{array}{l}\text { Tier } 1 \text { Capital Ratio } \\
\text { Tier } 1 \text { Capital / RWA, in \% }\end{array}$ & 1283 & 0.17 & 0.15 & -0.16 & 2.12 \\
\hline RISK & $\begin{array}{l}\text { RWA / Total Assets + Off Balance } \\
\text { Sheet Exposure, in \% }\end{array}$ & 1283 & 0.46 & 0.27 & 0.00 & 2.44 \\
\hline LG & $\begin{array}{l}\text { Annual change in volumes of loans to } \\
\text { private sector (t-1), in } \%\end{array}$ & 1283 & 0.01 & 0.08 & -0.17 & 0.35 \\
\hline GDP & Annual growth rate of GDP (t-1), in \% & 1283 & 2.10 & 3.03 & -7.80 & 10.80 \\
\hline $\mathrm{C}_{\mathrm{t}}$ & $\begin{array}{l}\text { Dummy that takes value } 1 \text { in the } 2007 \text { - } \\
2009 \text { and } 0 \text { elsewhere }\end{array}$ & 1283 & 0.175 & 0.380 & 0 & 1 \\
\hline
\end{tabular}

Source: Annual financial data from BankFocus, own calculations.

The dummy represents the value of 0 in normal times 2010-2016 and 1 in the time of crisis 2007-2009. The dummy $C_{t}$ aims at capturing the effect of the financial crisis. Hence, in our econometric model we apply a two period panel data analysis as follows:

$$
\begin{aligned}
& L R_{i t}=\beta_{0}+\delta_{0} C_{i t}+\beta_{1} T A_{i t}+\delta_{1} C_{t} T A_{i t}+\beta_{2} R I S K_{i t}+\delta_{2} C_{t} R I S K_{i t}+ \\
+ & \beta_{3} K_{i t}+\delta_{3} C_{t} K_{i t}+\beta_{4} K R_{i t}+\delta_{4} K R_{i t}+\beta_{5} \operatorname{Loan}_{i t-1}+\beta_{6} G D P_{i t-1}+a_{i+} \varepsilon_{i t}
\end{aligned}
$$

The control variables in the model equation (4) are chosen to reflect the cyclical qualities and to explain banks' choice of the target capital structure and the risk profile of the banks. TA represents the amount of the total assets of the banks (log of total assets is applied to eliminate significant differences in the asset size across countries). The risk profile of institutions is represented by the risk density $R I S K_{i}=\frac{R W A_{i}}{E X P_{i}}$ that equals to the risk weighted assets divided by total assets plus offbalance sheet exposure (as an approximation of the Basel III exposure measure). The interpretation of the risk density is explained earlier in the paper in equation (2). This component will be useful in understanding the adjusting business and risk strategies of the banks in response to changes in the economic cycle and regulatory requirements. $\mathrm{K}$ denotes the capital Tier 1 capital (similarly expressed in $\log$ terms). In our analysis, we try to assess the contribution of Tier 1 capital to the cyclical fluctuations in the leverage ratio. $\mathrm{KR}_{\mathrm{t}}$ denotes the capital ratio, defined as the Tier 1 capital divided by the total risk weighted assets. The statistical relations between the Tier 1 capital ratio and Basel III leverage are of interest for us to understand the patterns of ratios co-movements in various economic conditions (cyclical qualities).

The indicators of economic cycle are represented by annual growth in GDP and changes in domestic credit to the private sector from the World Bank data. The 
annual change in $\mathrm{GDP}_{\mathrm{it}-1}$ growth reflects the economic cycle of the countries in our model similarly to Fungácová and Jakubík (2012). Both variables are lagged (t-1) with one year period to capture the delayed effect of the macroeconomic circumstances on the microeconomic level of the banking system reflected in the annual or year-end financial statements of the commercial banks (Ayuso et al., 2004). In addition, there might be time-invariant fixed effects due to the counties' profile and, captured by $\alpha_{\mathrm{i}}$, and the regular unobserved factor is $\varepsilon_{\mathrm{it}}$.

\section{Results}

In Table 5 we show the results of the estimation of equation (4). The analysis of the components and variables allows us to disentangle the leverage ratio movements in reactions to the changes in economic conditions. First, we tried to assess the interaction of Basel III leverage ratio with the Tier 1 capital ratio over the cycle. The pattern emerged that the leverage ratio in normal times is strongly related to the capital ratio which is also true for the Czech and Slovak banks. Basel III leverage ratio shows strongly counter-cyclical movement with the Tier 1 capital ratio during the economy downturn and pro-cyclical qualities at normal times. Similar to the previous analysis, Basel III leverage ratio has a strong negative correlation with total assets at normal times and to a lesser extent at periods of a crisis. The coefficients are statistically significant and with negative signs.

The statistics evidences of the risk taking strategy of the banks measured by the risk density (RWA / EXP) have significant coefficients with positive signs. These might suggest that the banks manage actively their balance sheets and reduce the riskiness of their portfolios over the downturn period which is valid also for the banking sectors in the CEE and the Czech and Slovak banks. The reaction of the banks to cycle conditions can be translated into the banks' need to reduce the overall riskiness of their portfolios, or to deleverage in reaction to the crisis similarly as mentioned by Atkinson and Blundell-Wignall (2010) and Cathcart et al. (2013).

Over the period of 2007-2016, the leverage ratio does not reveal strong relation to the economic indicators such as loan volumes to the private sector or the GDP annual growth. This might be explained by the delayed macro effects on the banking sector. 
Janda, K. - Kravtsov, O.: Basel III Leverage and Capital Ratio over the Economic Cycle in the Czech Republic and its Comparison with CEE Region.

\section{Tab. 5 The comparison of regression results for the CEE and the Czech Republic, Slovakia}

\begin{tabular}{|c|c|c|c|c|c|c|}
\hline $\begin{array}{l}\text { Dependent Variable } \\
\text { Leverage Ratio }\end{array}$ & CEE count & tries & & Czech Repu & Iblic \& Sl & vakia \\
\hline Independent Variables & Coef. & t values & $\begin{array}{l}\text { P values } \\
<0.05\end{array}$ & Coef. & t values & $\begin{array}{l}P \text { values } \\
<0.05\end{array}$ \\
\hline TA & $-0.0338 * *$ & -2.92 & 0.004 & $-0.0282 * *$ & -2.50 & 0.0130 \\
\hline Tier 1 Capital & 0.0277 & 2.19 & 0.029 & 0.0274 & 2.19 & 0.0290 \\
\hline Tier 1 Ratio & $0.4015^{* *}$ & 13.17 & 0.000 & $0.4307 * *$ & 17.22 & 0.0000 \\
\hline RISK & $0.1086 * *$ & 4.59 & 0.000 & $0.2019 * *$ & 6.57 & 0.0000 \\
\hline TA in Crisis & -0.0096 & -1.40 & 0.163 & 0.0009 & 0.10 & 0.9190 \\
\hline $\mathrm{T} 1$ in Crisis & 0.0139 & 1.46 & 0.144 & -0.0038 & -0.34 & 0.7320 \\
\hline RISK in Crisis & $0.0450 * *$ & 2.49 & 0.013 & 0.0215 & 0.77 & 0.4420 \\
\hline Tier1 Ratio in Crisis & $-0.1716^{* *}$ & -3.73 & 0.000 & -0.0498 & -1.61 & 0.1100 \\
\hline Loan Volumes (t-1) & 0.0017 & 0.14 & 0.889 & 0.1127 & 0.87 & 0.3850 \\
\hline Growth GDP (t-1) & 0.0000 & 0.07 & 0.941 & 0.0008 & 0.31 & 0.7570 \\
\hline _cons & 0.0794 & 1.84 & 0.066 & -0.0129 & -0.31 & 0.7560 \\
\hline Obs & 1283 & & & 281 & & \\
\hline Banks & 320 & & & 22 & & \\
\hline F test & 0.0000 & & & 0.0000 & & \\
\hline R-sq & 0.8411 & & & 0.9013 & & \\
\hline
\end{tabular}

Source: Annual financial data from BankFocus and STATA calculations.

Note: $* *$ denotes $\mathrm{p}$ - values below $<0.05$.

\section{Conclusion}

This paper examines the implications and effectiveness of the leverage measure as a macroprudential policy for the banking sector of the CEE region. We describe and model the interdependencies between the leverage and capital ratio, define their constraining factors and assess the cyclical qualities. In the empirical study, we use the data sample containing financials of 320 major banks operating in seven countries of the CEE over the period 2007-2016.

The analysis of correlation patterns of the leverage and capital ratios underline the fact that Basel III leverage ratio and the Tier 1 capital ratio tend to co-move at normal times and a slightly counter-move at the time of a downturn or upswing. The correlation analysis further indicates that the total assets (or exposure) in contrast to the Tier 1 capital are the main contributors to the cyclical movements in the leverage. 
The results of the regression analysis show that Basel III leverage ratio in normal times is strongly related and more pro-cyclical to the Tier 1 capital ratio and, contrariwise, it reveals strong counter-cyclical tendencies over the crisis period. The results across the CEE banks show weaker relation between the leverage and total assets and the Tier 1 capital over the crisis period.

Our study might suggest that the banks are actively managing their balance sheets by adjusting to the targeted leverage and the capital structure over the cycles. The statistics from the banking sector of the CEE region and particularly the Czech Republic, Slovakia reveals tendencies of the banks toward optimisation of the riskweighted assets and structuring the portfolios with lower-risk assets. Under the situation of a declining risk-weights, the leverage regulatory constraint gains more importance and serves as a complementary measure to the risk-based requirements. Responses of the financial institutions to the changes in economic cycles advocate in favour of constraining regulations on the leverage.

\section{References}

Adrian, T., Shin, H. S., 2008. Financial intermediary leverage and value at risk (text No. 338). Federal Reserve Bank of New York.

Adrian, T., Shin, H. S., 2010. Liquidity and leverage. Journal of Financial Intermediation 19, 418-437. DOI: 10.1016/j.jfi.2008.12.002.

Atkinson, P., Blundell-Wignall, A., 2010. Thinking beyond Basel III. OECD Journal: Financial Market Trends 2010, 9-33. DOI: 10.1787/fmt-2010$5 \mathrm{~km} 7 \mathrm{k} 9$ tpcjmn.

Avery, R. B., Berger, A. N., 1991. Risk-based capital and deposit insurance reform. Journal of Banking \& Finance 15, 847-874. DOI: 10.1016/03784266(91)90103-s.

Aymanns, C., Farmer, J. D., 2015. The dynamics of the leverage cycle. Journal of Economic Dynamics and Control 50, 155-179. DOI: 10.1016/j.jedc.2014.09.015.

Ayuso, J., Perez, D., Saurina, J., 2004. Are capital buffers pro-cyclical? Evidence from Spanish panel data. Journal of Financial Intermediation 13, 249-264. DOI: 10.1016/s1042-9573(03)00044-5.

Baxter, M., King, R. G., 1999. Measuring Business Cycles: Approximate BandPass Filters for Economic Time Series. The Review of Economics and Statistics 81, 575-593. DOI: 10.1162/003465399558454.

BCBS, 2011. Basel III: A global regulatory framework for more resilient banks and banking systems - revised version June 2011.

BCBS, 2014. Basel III leverage ratio framework and disclosure requirements. BCBS, 2017. Basel III Monitoring Report February 2017. 
Janda, K. - Kravtsov, O.: Basel III Leverage and Capital Ratio over the Economic Cycle in the Czech Republic and its Comparison with CEE Region.

Berardi, S., Marcelletti, A., 2017. Optimal Bank Capital Requirements: An Asymmetric Information Perspective. SEP Working Paper.

Berger, A. N., Bouwman, C., 2013. How does capital affect bank performance during financial crises? Journal of Financial Economics 109, 146-176. DOI: 10.1016/j.jfineco.2013.02.008.

Brei, M., Gambacorta, L., 2016. Are bank capital ratios pro-cyclical? New evidence and perspectives. Economic Policy 31, 357-403. DOI: 10.1093/epolic/eiw001.

Cathcart, L., El-Jahel, L., Jabbour, R., 2013. The Basel Capital Requirement Puzzle: A Study of Changing Interconnections between Leverage and Risk-Based Capital Ratios.

Cevik, R. K., Dibooglu, S., Kutan, A. M., 2016. Real and Financial Sector Studies in Central and Eastern Europe: A Review. Czech Journal of Economics and Finance 66, 2-31.

EBA, 2016. European Banking Authority 2015 Annual Report.

Estrella, A., Park, S., Peristiani, S., 2000. Capital ratios as predictors of bank failure. Economic Policy Review, June 2012, 33-52.

Fender, I., Lewrick, U., 2015. Calibrating the leverage ratio. BIS Quarterly Review, December 2015.

Fungácová, Z., Jakubík, P., 2012. Bank Stress Tests as an Information Device for Emerging Markets: The Case of Russia. Working Papers IES No. 2012/04, Charles University Prague, Faculty of Social Sciences, Institute of Economic Studies.

Gropp, R., Heider, F., 2010. The Determinants of Bank Capital Structure. Review of Finance 14, 587-622. DOI: 10.1093/rof/rfp030.

Izák, V., 2011. The Welfare State and Economic Growth. Prague Economic Papers 20, 291-308. DOI: 10.18267/j.pep.401.

Janda, K., 2011. Inefficient Credit Rationing and Public Support of Commercial Credit Provision. Journal of Institutional Theoretical Economics167, 371-391. DOI: 10.1628/093245611796590021.

Janda, K., Michalikova, E., Skuhrovec, J., 2013. Credit Support for Export: Robust Evidence from the Czech Republic. World Economy 36, 1588-1610. DOI: 10.1111/twec.12061.

Kalemli-Ozcan, S., Sorensen, B., Yesiltas, S., 2011. Leverage Across Firms, Banks, and Countries (No. w17354). National Bureau of Economic Research, Cambridge, MA. DOI: 10.3386/w17354.

Kellermann, K., Schlag, C., 2013. Occupy risk weighting: how the minimum leverage ratio dominates capital requirements: A Swiss example. Journal of 
Financial Regulation and Compliance 21, 353-372. DOI: 10.1108/JFRC-06-20120019.

Klinger, T., Teply, P., 2016. The Nexus Between Systemic Risk and Sovereign Crises. Czech Journal of Economics and Finance 66, 50-69.

Matejasak, M., 2015. Did the Czech and Slovak Banks Increase their Capital Ratios by Decreasing Risk, Increasing Capital or Both? Procedia Economics and Finance 25, 256-263. DOI: 10.1016/S2212-5671(15)00736-4.

Musílek, P., 2011. European System of Financial Supervision. Český Finanční a Účetní Časopis 2011, 7-17. DOI: 10.18267/j.cfuc.102.

Nuño, G., Thomas, C., 2017. Bank Leverage Cycles. American Economic Journal: Macroeconomics 9, 32-72. DOI: 10.1257/mac.20140084.

Stádník, B., Miečinskienè, A., 2015. Complex Model of Market Price Development and its Simulation. Journal of Business Economics and Management 16, 786-807. DOI: 10.3846/16111699.2015.1076028.

Š́torová, B., Teplý, P., 2014a. The Level of Capital and the Value of EU Banks under Basel III. Prague Economic Papers 23, 143-161. DOI: 10.18267/j.pep.477.

Š́torová, B., Teplý, P., 2014b. EU Banks’ Profitability and Risk Adjustment Decisions under Basel III. Journal of Economics 62, 667-691.

Vejdovec, O., Teply, P., 2012. An Analysis of Economic Capital Allocation of Global Banks. World Academy of Science Engineering and Technology 6, 953956. 
